\title{
柵による空き地の閉鎖状況と市街化進行程度との関係 について
}

\author{
A Study on Vacant Lots Enclosed by Fences in Relation to Urbanization \\ 林 将之* 田代順孝** 木下 剛** \\ Masayuki HAYASHI YORITAKA TASHIRO Takeshi KINOSHITA
}

\begin{abstract}
摘要：子どもにとって空き地は公園にはない自然性や身近さを持った遊び場となりうるが，都市部で は柵で囲われた空き地も目立つ。本研究では，このような閉鎖された空き地の実態を把握し，今後の 緑地計画の一助とすることを目的として，その基礎的特性や市街化との関係について調べた。対象と した松戸市内の $900 \mathrm{ha}$ を調查した結果. 219 筒所の空き地を確認，うち $42 \%$ にあたる 93 箇所で閉鎖 がみられた。空き地の総面積は公園総面積とほほ等しかったが，市街化の進んだ地区ほど開鎖された 空き地の割合が増えるという相関がみられ，高密市街地における空き地の実態が明らかになると同時 にその潜在的価値が認められた。
\end{abstract}

\section{1. 背景之目的}

近年，人と自然との関係を再考しようという倾们が高まってお り，中でも，幼少期における遊びを通じた自然体験の重要性は， 既に多くの面から唱われている。この背景の一つには, 都市化に 伴う環境の変化により, 子よ゙屯の遊び形態が大きく変わってきて いることが挙げられ", 都市部における自然空間の減少や, 公園 以外の身近な自然空間の必要性が指摘されている ${ }^{233}$ 。

そんな中，空き地という空間は，従来より市街地内部に存在す る空間であり，子よ゙もたちの身近な遊び場としての役割も担って きたが ${ }^{2 / 33}$, 自然性という面から類别しても, 街区公園の緑が二次 的自然（man-made）に含まれるのに対し，空き地の草地はよ り自然性の高い二次的自然（semi-natural）に含まれると考え られる4 。同時に私的空間であるという面では独特な雲网気も持つ ており，仙田らの表現をを用いれば，子よ゙むたちが欲しているア ジトスペースやアナーキースペースとなりうる空間で，公園には ない刺激的な要素をあわせ持つ。しかし都市部においては, 管理 上の理由などから柵で閉鎖された空き地も目立ち，子どもたちの 野外遊び場として屯活用できない場合が多い6)。

このように，空き地はその公開性によって空間としての価值が 大きく異なるが，暫定的，私的という曖昧な性格が強いこともあ り, 従来から研究題材にされることは少なく, 特に空き地の公開 性に主眼を抢いた既往研究は全く見られない。そこで本研究では, オープンスペース（以下OS）としての空き地のポテンシャルを 見直し，子どもの遊び環境を考える立場から，都市における空き 地の実状を把握することを目的として，柵の設置による筀き地の 閉鎖性に着目して研究を進めた。本稿では，都市部に㧍ける空き 地の閉鎖状況之その存在特性を調べる之同時に, 都市化による地 域格差を明らかにするため，市街化進行程度との関係を調へ，空 き地を含めた緑地計画に関する基礎的情報を得ようと試みた。

\section{2. 研究の方法}

既往研究によると, 空き地の発生は市街化や地価上昇による農 耕の放裹, 土地の先行取得などによるものが多く”，市街化の進 行に伴ってその総量は, 蓄積, 飽和, 放出, 収束へ之移行し, 農 林地の宅地化之宅地の再編成上いう变容の中で媒介的な働きをし ている ${ }^{8)}$ と述べられている。また公共所有の空き地では, 物納で 納められた土地が, 売却, 利用されずに残っているものや, 都市
計画道路なよ゙将来的な計画のために用地確保してあるものなよ゙が ある。

本研究ではこのような空き地に対して，閉鎖性という特殊な視 点から分析を行うため，その属地情報に関する実態把握と基礎的 特性を明らかにすることに主眼をおいた。まず，「空き地」や 「閉鎖」の定義を行った上で，設定範同内から現地踏查により 「空き地」に該当するものをすべてピックアップし，それらを柵 の有無などから「開放空き地」と「閉鎖空き地」に分類した。次 にメッシュ法により市街化進行度 (宅地率)を算出して, 閉鎖空 き地の分布との相関を調べた。さらに個々の空き地の属性として, 面積, 経年数, 所有者, 発生起源なよ゙を取り上げ, これらと空き 地の閉鎖状況，市街化進行度との関係を多角的に分析した。

\section{（1）調査範囲地の概要}

首都圈 20km圈域の住宅系都市である松戸市を対象に，市の発 行する $1 / 2500$ の地形网枠に合わせて，JR 松戸駅から八柱駅間 の私鉄沿線を含む南北 $2250 \mathrm{~m} \times$ 東西 $4000 \mathrm{~m}$ 万形の $900 \mathrm{ha}$ を調査 範囲に設定した。範囲設定にあたっては，市の中心部から郊外ま でを含めることにより，市街化進行度との関係を見出しやすいよ うに考慮した。対象地は, 標高 $40 \mathrm{~m}$ 以下の低丘陵地带で起伏も 比較的多い。全面積中 $89 \%$ が市街化区域であり，土地利用の内 訳は約 8 割が市街地・道路, 1 割が農地（畑地中心), 残りの 1 割がその他の緑地となっている。調査範囲内の全人口は約 83,000 人, 人口密度は約 9,200 人 $/ \mathrm{km}^{2}$ あ゙ある。

\section{(2) 研究対象の定義}

本研究では，空き地に「自然性を持った子よ゙もの遊び場」とし ての価值を見出している点に留意し，吥究刘象となる空き地の条 件を形態上の面から次のように定めた。(1)地面より発生した草地 の状態にある。(2)現時点で明確な利用目的がなく，目立った維持 管理がなされていない。(3)宅地または農地としての利用価值を持っ た平坦地。(4)公道之の接触面をむつ。(5)概秝 $100 \mathrm{~m}^{2}$ 以上の面積を 有する。よって以トのような土地は対象外とした。対象外：公園, 社寺境内, 庭地, 植栽地, 農地, 林地, 河原, 斜面地, 駐車場, 舗装地，造成中の土地など。

(3)「閉鎖」の定義

本研究では「閉鎖」を次のように定義した。閉鎖：「接道部に おいて，柵などの物理的障害物を設置することにより，第三者の 当地への立ち入りを拒むこと。」さら事前調査を通して，閉鎖

*フリーランス ${ }^{* *}$ 千葉大学園芸学部緑地・環境学科 
の程度を示す「閉鎖強度」という 6 段階（（＜wide>５）の指標を設定 した (図一 1$)$ 。閉鎖強度は, 柵の構造, 素材, 設置範囲といっ た物理的状態と，それらが与える心理的影響を踏まえて総合的に 判断した指標であり, 閉鎖強度 3 未満のものを「開放」, 3 以上 のあのを「閉鎖」とみなすことにより，すべての空き地を開放か 閉鎖かに分類できるようにした。なお，空き地の閉鎖に関する明 確な制度等は一切存在しないが, 物納地 (大蔵省管轄) や都市計 画道路予定地（建設省管轄）などの公共所有の空き地では, 管理 責任上柵を設置することが一般化しているようである ${ }^{9)} 。$

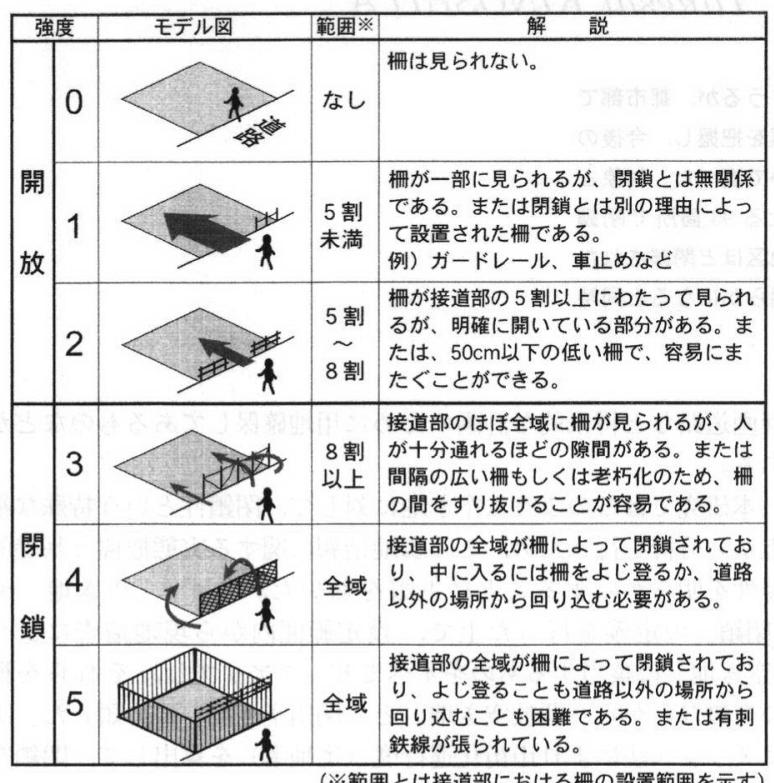

図-1 閉鎖強度モデルとその解説

\section{（4）宅地率の設定}

本研究では, 市街化の進行程度を表すむのとして「宅地率」と いう指標を設定した。宅地率は, 全面積中の宅地敷地面積（ただ し学校のグランドや大型建物敷地内の OS, 駐車場等は除く）の 割合を百分率で示したものであり, 調査範用に 3 行 $\times 4$ 列の大メッ シュ（1メッシュ $750 \times 1000 \mathrm{~m} ）$ をかけたものと, さらにそれを 4 分割して 6 行 $\times 8$ 列の小メッシュ $(375 \times 500 \mathrm{~m})$ にしたものよ, 2 段階に分けて算出した。面積測定は $1 / 10,000$ 地形図上で CAD を用いて行った。また市街地の性質による差異を調べるた めに, 用途地域別に宅地率を求めたものも分析に用いた。

\section{（5）空き地の属性調査項目}

空き地の基礎的属性として, 面積, 経年数 (存在期間), 土地 起源 (過去の土地利用), 所有者を主要調查項目に設定した。面 積は $1 / 2,500$ 地形図上で CAD を用いて測定, 経年数と土地起 源は, 最近 4 時点 ( $3,10,15,20$ 年前) の $1 / 2,500$ 地形図か ら読み取り, 所有者は土地課税台帳より調べた。また現地踏查で は, 柵の形態, 草の繁茂状態10), 看板, 不法投棄物の有無などの 現況を記録した。

\section{3. 調查結果と分析}

\section{（1）空き地の実態と閉鎖状況}

【閉鎖空き地の割合】1/2500 地形図をベースに現地踏查（1998 年 11１2月）を行った結果，空き地 219 箇所を確認，うち $42 \%$ にあたる 93 箇所が閉鎖空き地であった（以下，全空き地数に対 する閉鎖空き地数の割合を「空き地閉鎖率」と呼ぶ）。空き地の 総面積は約 $11.4 \mathrm{ha}$ （うち 48\%にあたる $5.5 \mathrm{ha}$ は閉鎖）であり， これは全調査面積の $1.33 \%$ にあたった。単純平均すると, 約 3.9ha あたりに面積 $522 \mathrm{~m}^{2}$ の空き地が 1 ヶ所出現していることに
なる。閉鎖強度の内訳は図－2のグラフのようになっており，閉 鎖空き地の約半数は強度 3 で弱い閉鎖であったが, 強度 5 の空き 地も $11 \%$ (24 箇所), 面積比では 15\%にのぼった。

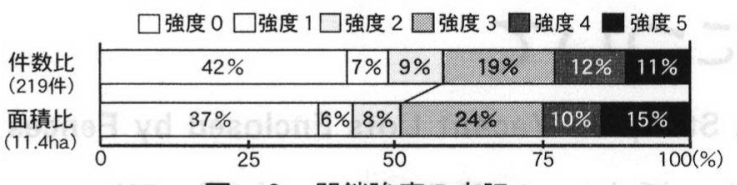

\section{図-2 閉鎖強度の内訳}

【柵の形態】高さは $100 \sim 130 \mathrm{~cm}$ のあの゙一般的で，素材・構造は 金網（フェンス）が最も多く,閉鎖空き地の $30 \%$ で見られ，次 いで木柵〈木杭＋番線〉 (28\%), 鉄柵〈鉄パイプなど〉 (26\%), 有刺鉄線 (12\%)，ロープ (11\%) などが多かった。これらを椢 の構造強度から分類すると, 番線等を用いた最屯簡易的な「簡易 仮設夕イプ」, 比較的頑強な作りの「仮設夕イプ」, 構造物となっ ている「設置タイプ」, 利用があった頃の囲いが残る「残存タイ プ」の4タイプに分けられた（写真－1）。これらが見られた空 き地の経年数を比較すると表一 1 のようになり, 残存タイプや簡 易仮設タイプの柵は暫定的性格の強い空き地で, 設置タイプの柵 は当面利用予定のない空き地で多く設けられるものと考えられた。
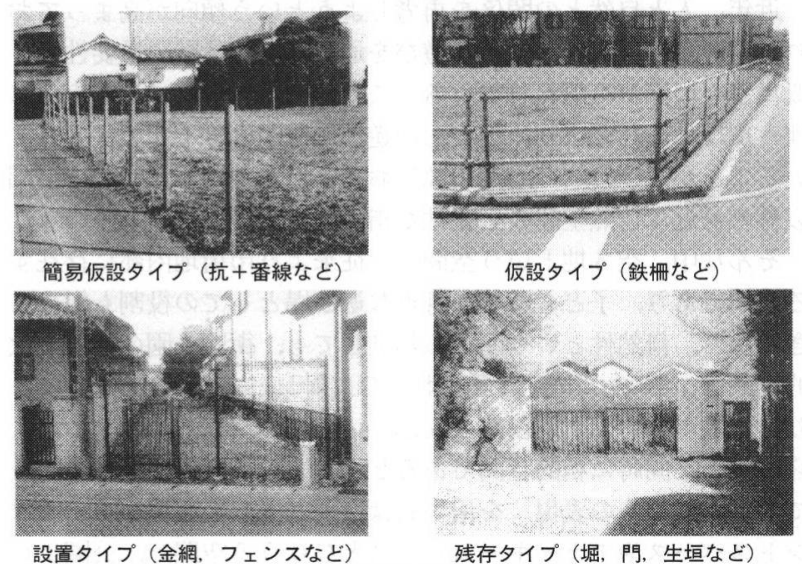

仮設タイプ（鉄柵など）

写真ー1 構造強度から分類した柵の形態

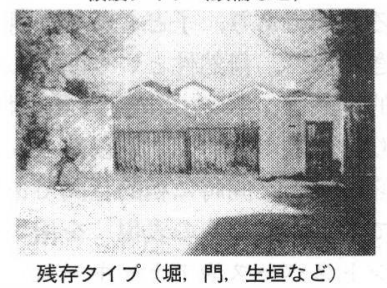

表 -1 柵の構造強度タイプと空き地の経年数

\begin{tabular}{|c|c|c|c|c|c|c|c|c|}
\hline \multirow{2}{*}{ タイプ } & \multirow{2}{*}{ 代表形態 } & \multirow{2}{*}{ 件数(割合) } & \multicolumn{5}{|c|}{ 空き地の経年数 } & \multirow{2}{*}{ 平均 } \\
\hline & & & $\sim 3$ & $3 \sim 10$ & $10 \sim 15$ & $15 \sim 20$ & $20 \sim$ & \\
\hline 残存夕夕17 & 㙋、門、生垣 & $16(17 \%)$ & $38 \%$ & $19 \%$ & $25 \%$ & $6 \%$ & $13 \%$ & 2.4 \\
\hline 簡易仮設夕夕17' & 木杭十番線 & $32(34 \%)$ & $25 \%$ & $38 \%$ & $13 \%$ & $3 \%$ & $22 \%$ & 2.6 \\
\hline 仮設夕イプ & 鉄柵 & $26(28 \%)$ & $23 \%$ & $19 \%$ & $4 \%$ & $8 \%$ & $46 \%$ & 3.4 \\
\hline 設鲁 $817^{\circ}$ & 金網、7ニ次 & $19(20 \%)$ & $5 \%$ & $16 \%$ & $21 \%$ & $11 \%$ & $47 \%$ & 3.8 \\
\hline \multicolumn{2}{|c|}{ 閉鎖空き地全体 } & $93(100 \%)$ & $23 \%$ & $25 \%$ & $14 \%$ & $6 \%$ & $32 \%$ & 3.0 \\
\hline
\end{tabular}

※平均 $\cdots$ 経年数のカテゴリーを経年数が短いものから 1 5 に指数化して算出

【空き地の現況】看板 （広告を除く）が設置 された空き地と, ゴミ の不法投棄が目立った 空き地の件数を表 -2 に示す。看板の設置さ れた空き地は全体的に 少なく，立入抑制を示
表－2 看板とゴミの不法投棄の現況

\begin{tabular}{|c|c|c|c|c|c|}
\hline \multicolumn{2}{|c|}{ 項 目 } & 件数(割合) & 内 訳 & 件数※ & 閉鎖率 \\
\hline & なし & $183(84 \%)$ & - & - & $38 \%$ \\
\hline \multirow{3}{*}{$\begin{array}{l}\text { 看 } \\
\text { 板 }\end{array}$} & \multirow{3}{*}{ あり } & \multirow{3}{*}{$36(16 \%)$} & 所有. 売買 & 19 & $60 \%$ \\
\hline & & & Z'ミや犬のマナー & 15 & $60 \%$ \\
\hline & & & 立入抑制 & 8 & $100 \%$ \\
\hline \multirow{3}{*}{$\Xi$} & なし & $136(62 \%)$ & - & - & $43 \%$ \\
\hline & \multirow{2}{*}{ あり } & \multirow{2}{*}{$83(38 \%)$} & 粗大ざミなし & 69 & $49 \%$ \\
\hline & & & 粗大ごミあり & 14 & $7 \%$ \\
\hline
\end{tabular}

すあのはわずか 8 筒所であった。一方ゴミの不法投棄は, 空き地 の閉鎖開放に関係なく見られたが，粗大ゴミが見られた空き地に 限っていえば, 14 箇所中 13 箇所が開放空き地であり, 空き地の 閉鎖の背景には，粗大ゴミの不法投棄問題も大きく影響している と考えられた。

\section{（2）空き地の閉鎖と宅地率の関係}

メッシュ法により宅地率を算出した結果, 調査範囲全体では $52.1 \%$, 小メッシュの宅地率は最低 $8.2 \%$, 最大 $73.0 \%$ であった。 
これを 5 段階にランク分けして，空き地の分布とともに示したも のが図ー 3 である。図中の太線枠 $(A \sim K)$ は大メッシュ, 細線 枠は小メッシュを示している ${ }^{11)}$ 。

この節では, 空き地量や閉鎖率, 宅地率を大メッシュごとに求 めて，それぞれの関係を調べた。1大メッシュの面積は75haで， これは都市公園設置基準の近隣公園誘致圈（半径 $500 \mathrm{~m} ; 78.5 \mathrm{ha}$ ) とほぼ一致するが，1大メッシュ当たり空き地出現数は平均 19.1 箇所と, 都市計画上の公園数（近隣公園 1 , 街区公園 4 ） と比べても高い值を示した。大メッシュごとの緑地面積内訳と空 き地量を示したあのが図ー4である（宅地率の高い大メッシュ順 に並べて示す)。空き地量が特に多かった C ・ D ・ H は, 市街化 縁辺部にあたり, 内包する小メッシュの宅地率の高低差が大きい 地区であった。全体では，空き地総面積は緑地全体の約 $8 \%$ を占 め, 公園総面積とほぼ等しかったが，大メッシュ別にみると，公 園面積の少ないメッシュで空き地面積が多いといった関係がやや みられ，閉鎖空き地の面積が公園面積を上回る地区が 3 地区あっ たなど，緑地としての空き地の潜在的価值が伺えた。

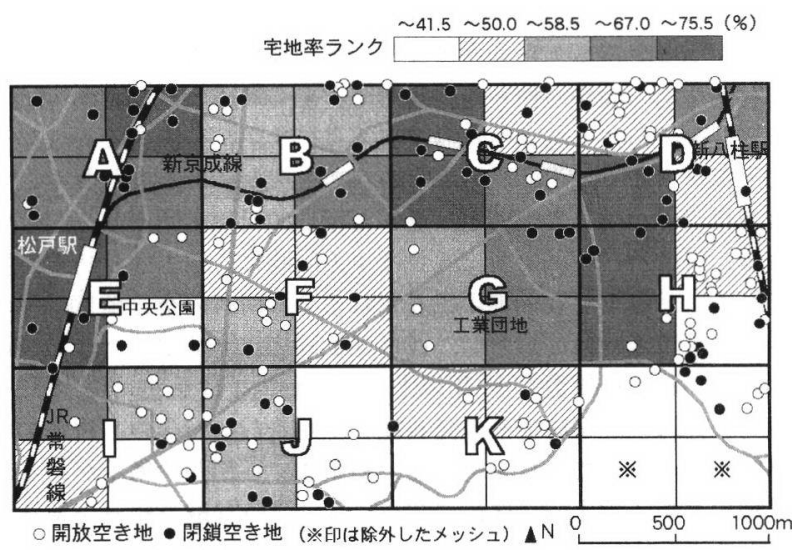

図一３空き地の分布と宅地率

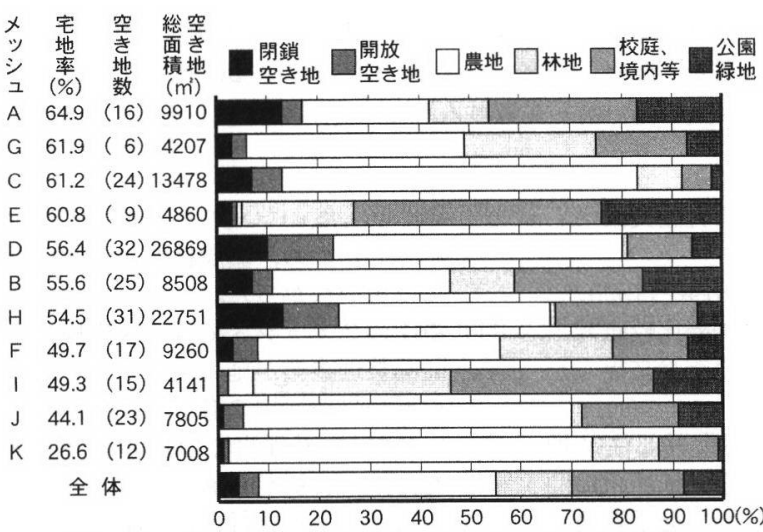

図ー4 大メッシュ別の緑地面積内訳と空き地量

大メッシュごとの宅地率 と空き地閉鎖率を散布図に したものが図ー5であるが, 二者の間には正の相関がみ られ，相関係数は.712 で 危険率 5 \%水準で有意であっ た。

市街地の性質による違い を調べるために，用途地域 別に空き地閉鎖率をみると (表-3), 商業系地域が最 6高く，工業系地域は宅地

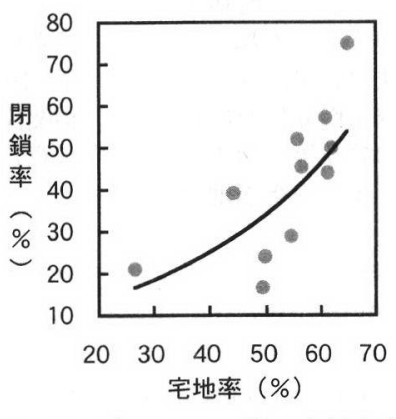

図一 5 大メッシュ別の宅地率と 空き地閉鎖率の散布図
率の割に閉銷率が非常に低いという特徵がみられた。また出現率 についても各地域で大きな差異が認められた。

表一 3 用途地域別の空き地出現数と閉鎖率

\begin{tabular}{|c|c|c|c|c|c|c|}
\hline 地域名 & 面積 & 宅地率 & 空き地件数 & 仵数/75ha & 平均面積 & 閉鎖率 \\
\hline 低層住居専用地域 & $223 \mathrm{ha}$ & $52.9 \%$ & 81 & 27.2 & $640 \mathrm{~m}^{2}$ & $37 \%$ \\
\hline 中層住居専用地域 & 98ha & $61.2 \%$ & 30 & 23.0 & $496 \mathrm{~m}^{2}$ & $57 \%$ \\
\hline 淮居·準住居地域 & $267 \mathrm{ha}$ & $50.9 \%$ & 81 & 22.8 & $437 \mathrm{~m}^{2}$ & $42 \%$ \\
\hline 商業系地域 & 109 ha & $72.5 \%$ & 15 & 10.3 & $407 \mathrm{~m}^{2}$ & $67 \%$ \\
\hline 工業系地域 & $101 \mathrm{ha}$ & $56.4 \%$ & 6 & 4.5 & $431 \mathrm{~m}^{\prime}$ & $17 \%$ \\
\hline 市街化調整区域 & $65 \mathrm{ha}$ & $13.8 \%$ & 6 & 6.9 & $599 \mathrm{~m}$ & $17 \%$ \\
\hline
\end{tabular}

（3）空き地の属性別にみた閉鎖率と宅地率の関係

次に，空き地の属性別にみた閉鎖率之，宅地率之の関係を調へ るため,クロス集計を中心とした分析を行った。諸属性の集計結 果は表一 4 の通りである。この節では，個々の空き地が存在する 小メッシュの宅地率ランク（図ー 2 参照）を分析に用いた。

表 -4 空き地の属性別の集計と閉鎖率

\begin{tabular}{|c|c|c|c|c|c|}
\hline 調查項目 & カテゴリー & 件数（割合） & 平均面積 & & 閉鎖率 \\
\hline \multirow[t]{6}{*}{ 面積 } & $200 \mathrm{~m}^{2}$ 以下 & $67(31 \%)$ & $133 \mathrm{~m}^{2}$ & $40 \%$ & 둘둘 \\
\hline & $200 \sim 400 \mathrm{~m}^{2}$ & $61(28 \%)$ & $290 \mathrm{~m}^{\prime}$ & $33 \%$ & 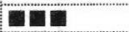 \\
\hline & $400 \sim 600 \mathrm{~m}^{2}$ & $30(14 \%)$ & $482 m^{2}$ & $47 \%$ & 뭄둘 \\
\hline & $600 \sim 800 \mathrm{~m}^{2}$ & $19(9 \%)$ & $682 \mathrm{~m}^{2}$ & $47 \%$ & 불물 \\
\hline & $800 \sim 1000 \mathrm{~m}$ & $16(7 \%)$ & $900 \mathrm{~m}^{2}$ & $50 \%$ & 물 \\
\hline & $1000 \mathrm{~m}^{2}$ 以上 & $26(12 \%)$ & $1771 \mathrm{~m}^{\prime}$ & $58 \%$ & पEve \\
\hline \multirow{4}{*}{$\begin{array}{c}\text { 土地起源 } \\
\text { ** }\end{array}$} & 空地 & $81(37 \%)$ & $410 \mathrm{~m}^{2}$ & $37 \%$ & 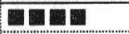 \\
\hline & 宅地 & $72(33 \%)$ & $414 \mathrm{~m}^{2}$ & $57 \%$ & 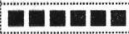 \\
\hline & 㚼地 & $58(26 \%)$ & $736 \mathrm{~m}^{2}$ & $31 \%$ & E \\
\hline & 林地 & $8(4 \%)$ & $1092 \mathrm{~m}^{2}$ & $50 \%$ & ara \\
\hline \multirow{3}{*}{$\begin{array}{c}\text { 所有者 } \\
* *\end{array}$} & 個人 & $147(67 \%)$ & $473 m^{2}$ & $34 \%$ & 口a \\
\hline & 法人 & $28(13 \%)$ & $577 \mathrm{~m}^{2}$ & $54 \%$ & an \\
\hline & 公共 & $44(20 \%)$ & $653 \mathrm{~m}^{2}$ & $64 \%$ & GEve \\
\hline \multirow{5}{*}{$\begin{array}{c}\text { 所有者所在地 } \\
\text { (個人所有の } \\
147 \text { 件対象) }\end{array}$} & $100 \mathrm{~m}$ 以内 & $28(19 \%)$ & $578 \mathrm{~m}^{2}$ & $25 \%$ & 둘 \\
\hline & $1000 \mathrm{~m}$ 以内 & $53(36 \%)$ & $471 \mathrm{~m}^{2}$ & $34 \%$ & ar \\
\hline & 市内 & $25(17 \%)$ & $675 \mathrm{~m}^{2}$ & $36 \%$ & 물 \\
\hline & 隣接都市 & $14(10 \%)$ & $286 \mathrm{~m}^{2}$ & $29 \%$ & ar \\
\hline & 卺隔地 & $27(18 \%)$ & $277 \mathrm{~m}^{2}$ & $44 \%$ & 口n \\
\hline \multirow[t]{5}{*}{ 経年数 } & 3 年以内 & $45(21 \%)$ & $855 \mathrm{~m}^{2}$ & $47 \%$ & 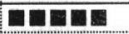 \\
\hline & $3 \sim 10$ 年 & $53(24 \%)$ & $419 \mathrm{~m}^{2}$ & $43 \%$ & 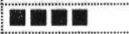 \\
\hline & $10 \sim 15$ 年 & $26(12 \%)$ & $523 \mathrm{~m}^{2}$ & $50 \%$ & 10日a \\
\hline & 15 20年 & $14(6 \%)$ & $524 \mathrm{~m}^{2}$ & $43 \%$ & ane \\
\hline & 20年以上 & $81(37 \%)$ & $405 \mathrm{~m}^{2}$ & $37 \%$ & 口E \\
\hline 全 & 体 & 219 & $522 \mathrm{~m}^{2}$ & $42 \%$ & 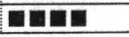 \\
\hline
\end{tabular}

(**印の項目は閉鎖率についてカイ 2 乗検定の結果、危険率 $1 \%$ 水準で有意差あり)
0\% $30 \% \sim 45 \% \sim 60 \% \sim 75 \% \sim$

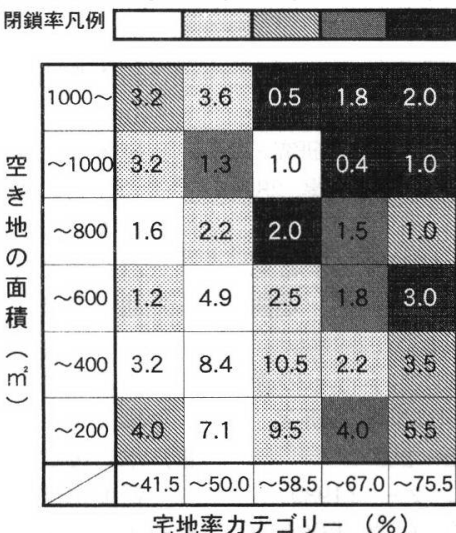

※中の数字は75ha当たりの空き地の出現数 （平均3.3件）を示し、色は閉鎖率を示す

図－6 宅地率ランクと面積別に示し た空き地閉鎖率と出現数 (i) 面積

全 219 箇所の空き地 の平均面積は $522 \mathrm{~m}^{2}$ で あったが， $400 \mathrm{~m}^{2}$ 以下 のものが約 6 割を占め, 一部の大面積のもの以 外は戸建て住宅地敷地 前後のものが大半であっ た。空き地の面積と宅 地率ランクを 2 軸に, 空き地閉鎖率と出現率 を表したものが恳ー6 であるが，低宅地率区 で小面積の空き地ほど 開放され，高宅地率区 で大面積の空き地ほど 閉鎖される傾向が読み 取れる。 (ii）土地起源 (過去の土地利用)

空き地になる以前の土地利用を過去 4 時点で調べたところ（4 時点全てにおいて利用のなかったものは「空地」とした，宅地 起源の空き地が圧倒的に閉鎖率が高かった。宅地率ランク別に起 源の比之閉鎖率をみたものが図一 7 であり，宅地率の高い地区で 宅地起源の割合が高かったが, 畑地, 空地起源ともに, いずれも 


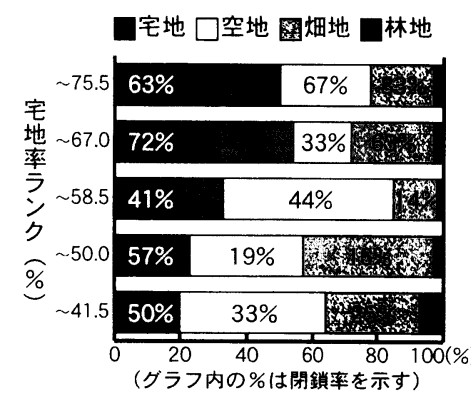

図ー7 宅地率ランク別にみた空 き地の起源比と閉鎖率

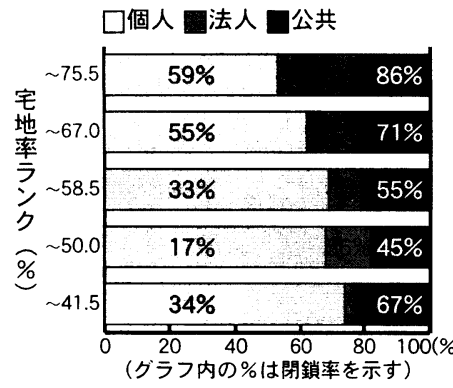

図ー8 宅地率ランク別にみた空 き地の所有比と閉鎖率
宅地率の高い地区で閉鎖率 が高かった。

\section{(iii) 所有者}

全空き地の約 7 割が個人 所有であったが，閉鎖率は 公共所有と法人所有のもの が压倒的に高く,これらは 平均面積も大きかった。法 人所有の空き地は, 宅地起 源ものが 6 割近くを占め, 公共所有の空き地（約半数 は物納による土地と思われ る）は, 土地起源に関わら ず閉鎖率が高いという特徵 がみられた。宅地率ランク 別にこの 3 者の所有比之閉 鎖率を示したものが図一 7 であり, 宅地率が高い地区 ほよ゙個人所有に代わって法 人所有が增える傾向があっ たが，閉鎖率はいずれも宅 地率の高い地区で高かった。 補足的に調べた所有者所 在地 ${ }^{22}$ では, 所有者が 100 $\mathrm{m}$ 以内に所在する場合の空 き地閉鎖率が最も低く, 逆に遠隔地の場合が最も高いという関係 がみられたことから, 所有者のアクセスの悪さも閉鎖に関わって いると考えられる。

(iv) 経年数（空き地の存在期間）

空き地の経年数と閉鎖率の間には特に相関はなかった。所有者 別にみた経年数でも大差はなく，個人所有の空き地で経年数 20 年以上の割合がやや高かった程度である。一方, 空き地の単位面 積之経年数の間には負の相関 ${ }^{133}$ があり, 特に $800 \mathrm{~m}^{2}$ 以上の大面積 の空き地では, 経年数 3 年以内である割合が $40 \%$ 之高く $\left(800 \mathrm{~m}^{2}\right.$ 未満では 16\%)，短期間のうちに土地利用されるものが多いと考 えられる。

\section{補注および参考文献}

1) 仙田満・岡田英紀 (1993)：こよ゙もの あそひ環境の構造的変化に関する研究 日本都市計画学会学術研究論文集 28 , $763-768$

2) 菅森記子・田畑貞寿（1986）：子よ゙も の自然遊びと緑地に関する研究：造園 雑誌 $49(5), 239-244$

3 ）佐藤丘・中村攻（1986）：子よ゙もの遊 びに供される地域空間に関する研究： 造園雑誌 49(5)，245-250

4 ) 農村生活総合研究センター（1989）: 農村的自然のもつ教育力：生活研究レ ポート 27, $10 \mathrm{pp}$

5 ) 三輪律江・仙田満・矢田努 (1992)： こどものあそび環境の国際比較研究:
日本都市計画学会学術研究論文集 27 , $487-492$

6 ）尾木まり・仙用満・矢田努 (1990) こどものあそび環境の国際比較研究： 日本都市計画学会学術研究論文集 25 , $217-222$

7 ）池田孝之（1976）: 大都市近郊住宅地 における空閑地の動向と整備計画に関 する考察：日本都市計画学会学術研究 論文集 11，1-6

8 ) 水[1俊典 (1982): 空閑地の土地利用 転換に関する予備的研究：日本都市計 画学会学術研究論文集 17, 67-72

9 ）松戸市役所，千葉財務事務所より確認。

10）松戸市では「空き地の雑草等の除去に 関する条例」のもと, 多くの空き地で
年 2 回程度の草刈りが不定期的に行わ れていたため, 繁茂状態は今回の分析 には用いなかった。

11）※印の 2 メッシュでは，大規模な土地 区画整理事業が施工中であったことと, 付近一帯が河川の遊水池に指定されて いるなど，特異的な土地利用状態であっ たため，分析から除外した。

12）所有者 (土地課税台帳に記載) 以外の 者がその土地管理を行っているケース も多いと考えられるため, 本研究では 参考程度の扱いとした。

13）全 219 筒所の空き地に対して算出した 相関係数は-.174（危険率 $1 \%$ 水準で 有意）であった。

Summary: Vacant lots would be children's play space possesses the nature and nearness, but we often find them enclosed by fences. Then I researched about them and the relation between fencing and urbanization, for the purpose of showing their actual condition and being of use to open space planning. The result of the research, I found 219 vacant lots on the fixed area of 900 ha in Matsudo City, 93 out of them (account for 42\%) were fenced. In the area, the total areas of vacant lots were as wide as those of parks, and it was confirmed that the rate of fenced vacant lots went up with urbanization, which showed the actual condition of vacant lots in built-up area and their potential value. 